\title{
艮改, 窯環輪式ンマフ木
}
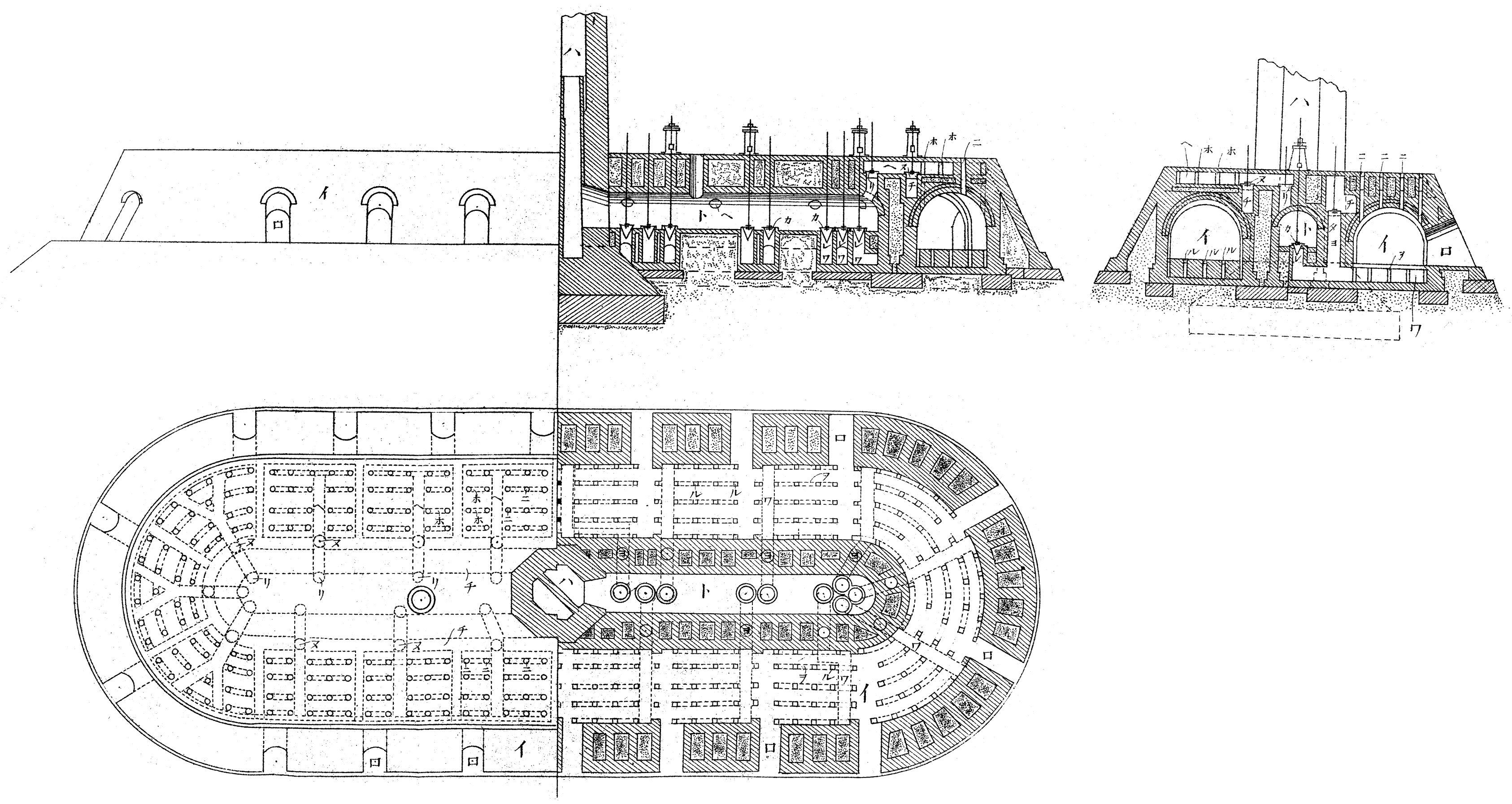